\title{
PRODUKTIVITAS KERJA DITINJAU DARI PENGEMBANGAN KARIR, MOTIVASI DAN SIKAP (STUDI PADA PT. BCA MULTIFINANCE SURAKARTA)
}

\author{
Tomi Irwan Trisnanto, Istiatin, Eny Kustiyah \\ Universitas Islam Batik Surakarta \\ Email : tomyirwan11@gmail.com
}

\begin{abstract}
The research aims to find out and describe the influence of simultaneously or partial career development, motivation and attitude towards work productivity in PT. BCA Multifinance Surakarta. This methodology research using quantitative descriptive research. The population was all employees PT. BCA Multifinance Surakarta is 47 people. The number of samples was determined with the formula Arikunto and the result 47 respondents. Sampling method using sensus sampling. The questionnaire used for data retrieval. Data analysis technique used was statistic analysis is multiple linier regression, $F$ test, $t$ test and determination coefficient. This test results the career development, motivation and attitude simultaneously and significance effect on work productivity in PT. BCA Multifinance Surakarta. Career development influential positive and significance effect against the work productivity in PT. BCA Multifinance Surakarta. Motivation influential positive and significance effect against the work productivity in PT. BCA Multifinance Surakarta. Attitude influential positive and significance effect against the work productivity in PT. BCA Multifinance Surakarta.
\end{abstract}

Keywords : Work Productivity, Career Development, Motivation, Attitude

\section{PENDAHULUAN}

Peningkatan produktivitas dapat terwujud, jika pimpinan perusahaan memahami secara tepat faktor penentu keberhasilan. Perusahaan mengharapkan karyawan dapat bekerja dengan baik dan memiliki produktivitas tinggi. Faktor penting dalam meningkatkan produktivitas tergantung pada manajemen perencanaan (Kustiyah, Pawastri dan Istiatin, 2018). Semua usaha untuk meningkatkan produktivitas dalam perusahaan, memerlukan manajemen yang kuat. Kualitas yang dimiliki karyawan menentukan produktivitas kerja. Meningkatkan kualitas karyawan dengan memberikan motivasi, pemahaman untuk mengetahui kemampuan dalam bekerja dan penilaian pengembangan karir.

Pengembangan karir menjadi salah satu cara yang dapat dilakukan perusahaan untuk meningkatkan produktivitas kerja. Peningkatan dalam berkarir dapat memberikan informasi kepada karyawan terkait posisi yang akan diraih. Adanya pengembangan karir, karyawan dapat terus termotivasi dan berusaha meningkatkan kemampuan dan loyalitas terhadap perusahaan. Pengembangan karir berpengaruh signifikan terhadap produktivitas kerja (Ismail, Rahma dan Pratiwi, 2015).

Selain pengembangan karir, motivasi juga mempengaruhi dalam peningkatan produktivitas kerja. Karyawan yang bersemangat dan bergairah dalam bekerja memiliki motivasi kerja. Hartanto, Febrianti dan Ani (2019) motivasi berpengaruh signifikan terhadap produktivitas kerja. Karyawan mempunyai motivasi kerja tinggi biasanya memiliki produktivitas kerja tinggi. Motivasi kerja karyawan perlu dibangkitkan dan dapat menghasilkan kinerja terbaik. Semakin tinggi motivasi dalam bekerja maka kinerja yang dihasilkan pun tinggi.

Sikap dan perhatian atasan menjadi salah satu kebutuhan karyawan dalam bekerja. Karyawan mengharapkan atasan melakukan kontrol terhadap diri seorang karyawan. Sikap kerja 
yang positif dalam hubungannya dengan perilaku karyawan, akan menguntungkan perusahaan. Sikap kerja berpengaruh signifikan terhadap produktivitas kerja (Asmuni dan Widiastuti, 2015). Sikap yang menyenangi pekerjaan akan menghasilkan tindakan yang baik. Karyawan yang bersikap baik akan berupaya maksimal memberikan hasil kerja terbaik dengan cara menepati ketentuan-ketentuan pekerjaan yang diberlakukan.

PT. BCA Multifinance menjadi salah satu perusahaan yang memberikan layanan pembiayaan kepada konsumen. PT. BCA Multifinance beralamtakan di Jl. Arifin No. 41 G Ruko 7-8 Kompleks Ruko Widuran, Kepatihan Kulon, Jebres, Surakarta. Jumlah karyawan yang bekerja di PT. BCA Multifinance cabang Surakarta sebanyak 47 orang. Berdasarkan hasil observasi dan wawancara awal dengan sejumlah karyawan, adanya fenomena produktivitas tiaptiap karyawan yang mengalami penurunan maupun peningkatan. Adanya peningkatan produktivitas kerja ditandai dengan adanya kesempatan yang diberikan perusahaan dalam melakukan pengembangan karir. Pengembangan karir dilakukan dengan memberikan pelatihanpelatihan yang diadakan tiap satu bulan sekali. Selain itu, adanya penurunan produktivitas kerja disebabkan karyawan memiliki motivasi yang rendah ditunjukkan dengan bentuk ketidakhadiran yang cukup tinggi. Ketika perusahaan mengadakan pengajian bulanan yang dilaksanakan setiap hari rabu awal bulan, namun masih banyak karyawan tidak hadir, mengindikasikan bahwa adanya permasalahan mengenai motivasi kerja. PT. BCA Multifinance juga mengawasi karyawan yang malas, tidak hadir tepat waktu dan tidak mencapai target. Berbagai sikap kerja karyawan PT. BCA Multifinance bervariasi dan tidak semua memiliki sikap kerja yang negatif. Namun memiliki sikap yang positif seperti karyawan yang pandai menghargai waktu, disiplin tinggi, memiliki tanggung jawab tinggi terhadap pekerjaan. Adanya sikap positif dari karyawan membuat perusahaan memberikan kesempatan kepada karyawan untuk mendapatkan fasilitas maupun bonus.

Berdasarkan uraian di atas, penulis tertarik untuk melakukan penelitian dengan judul Produktivitas Kerja ditinjau dari Pengembangan Karir, Motivasi dan Sikap (Studi Pada PT. BCA Multifinance Surakarta).

\section{METODOLOGI PENELITIAN}

Penelitian ini menggunakan penelitian kuantitatif. Penelitian ini dilakukan pada PT. BCA Multifinance beralamtakan di Jl. Arifin No. 41 G Ruko 7-8 Kompleks Ruko Widuran, Kepatihan Kulon, Jebres, Surakarta. Populasi dalam penelitian ini adalah seluruh karyawan PT. BCA Multifinance cabang Surakarta berjumlah 47 orang. Arikunto (2016: 116) penentuan pengambilan sampel, apabila jumlah populasi kurang dari 100 lebih baik diambil semua. Jadi jumlah sampel pada penelitian ini adalah 47 orang. Teknik sampling pada penelitian ini menggunakan sensus yaitu teknik penentuan sampel bila semua populasi digunakan sebagai sampel. Kuesioner digunakan untuk pengambilan data. Regresi linier berganda sebagai metode untuk menganalisis data.

\section{HASIL ANALISA DATA}

\section{Uji Asumsi Klasik}

\section{Hasil uji normalitas}

Menguji normalitas digunakan alat analisis Kolmogorov Smirnov, hasilnya adalah: 
Tabel 1. Hasil Uji Normalitas

\begin{tabular}{lcc}
\hline & $\begin{array}{c}\text { Unstandardized } \\
\text { Residual }\end{array}$ & Keterangan \\
\hline$N$ & 47 & Data terdistribusi \\
Kolmogorov-Smirnov $Z$ & 0,756 & normal \\
Asymp. Sig. (2-tailed) & 0,617 & \\
\hline
\end{tabular}

Hasil pengujian Kolmogrov Smirnov test menunjukkan bahwa nilai Asymp. Sig (2-tailed) lebih besar dari 0,05 $(0,617>0,05)$. Menunjukkan bahwa persamaan regresi untuk model dalam penelitian ini memiliki sebaran data yang normal.

\section{Hasil uji multikolinearitas}

Hasil yang di dapatkan dalam uji multikolinearitas adalah:

Tabel 2. Hasil Uji Multikolinearitas

\begin{tabular}{|c|c|c|c|}
\hline \multirow[t]{2}{*}{ Model } & \multicolumn{2}{|c|}{ Collinearity Statistics } & \multirow[t]{2}{*}{ Keterangan } \\
\hline & Tolerance & $V I F$ & \\
\hline Pengembangan Karir & 0,528 & 1,895 & $\begin{array}{c}\text { Tidak terjadi } \\
\text { multikolinearitas }\end{array}$ \\
\hline Motivasi & 0,488 & 2,049 & $\begin{array}{c}\text { Tidak terjadi } \\
\text { multikolinearitas }\end{array}$ \\
\hline Sikap & 0,898 & 1,113 & $\begin{array}{c}\text { Tidak terjadi } \\
\text { multikolinearitas }\end{array}$ \\
\hline
\end{tabular}

Berdasarkan hasil perhitungan pada tabel di atas, diperoleh nilai tolerance variabel pengembangan karir 0,528, nilai tolerance variabel motivasi 0,488 dan nilai tolerance variabel sikap 0,898, yang semuanya $>0,10$. Jadi model regresi pada penelitian ini tidak ada multikolinearitas antar variabel bebas.

\section{Hasil uji heteroskedastisitas}

Hasil yang di dapatkan dalam uji heteroskedastisitas adalah:

Tabel 3. Hasil Uji Heteroskedastisitas

\begin{tabular}{lcc}
\hline \multicolumn{1}{c}{ Model } & Sig. & Keterangan \\
\hline Pengembangan Karir & 0,307 & Tidak terjadi heterokedastisitas \\
Motivasi & 0,818 & Tidak terjadi heterokedastisitas \\
Sikap & 0,958 & Tidak terjadi heterokedastisitas \\
\hline
\end{tabular}

Berdasarkan tabel di atas menunjukkan bahwa nilai probabilitas (Sig.) dari masing-masing variabel independen adalah pengembangan karir bernilai 0,307, motivasi bernilai 0,818 dan sikap bernilai 0,958 yang ke semuanya lebih besar dari 0,05. Dapat dinyatakan model regresi ini tidak terjadi heteroskedastisitas. 


\section{Uji Hipotesis}

\section{Hasil regresi linier berganda}

Nilai a dan $b_{1}, b_{2}, b_{3}$ dalam uji regresi linier berganda adalah:

\begin{tabular}{lcc}
\multicolumn{2}{c}{ Tabel 4. Analisis Regresi Linier Berganda } \\
\hline \multicolumn{1}{c}{ Model } & \multicolumn{2}{c}{ Unstandarized } \\
& \multicolumn{2}{c}{ coefficients } \\
& $B$ & Std. \\
& & Error \\
\hline Constant & 0,309 & 2,949 \\
Pengembangan Karir & 0,349 & 0,137 \\
Motivasi & 0,393 & 0,164 \\
Sikap & 0,274 & 0,128 \\
\hline
\end{tabular}

Berdasarkan persamaannya adalah:

$\mathrm{Y}=0,309+0,349 \mathrm{X}_{1}+0,393 \mathrm{X}_{2}+0,274 \mathrm{X}_{3}+\mathrm{e}$

\section{Hasil uji F}

Perhitungan nilai $F_{h i t u n g}$ adalah:

Tabel 5. Hasil Uji F

\begin{tabular}{lccc}
\hline \multicolumn{1}{c}{ Model } & $F$ & Sig. & Keterangan \\
\hline Regressio & 17,459 & 0,000 & $\mathrm{H}_{0}$ ditolak, $\mathrm{H}_{1}$ diterima \\
$n$ & & & \\
Residual & & & \\
Total & & & \\
\hline
\end{tabular}

Hasil analisis data yang telah didapatkan, maka dapat diketahui bahwa nilai $F_{\text {hitung }}$ adalah sebesar 17,459, dikarenakan $F_{\text {hitung }}>F_{\text {tabel }}(17,459>2,82)$ dan signifikansi $0,000<0,05$ maka Ho ditolak. Dapat disimpulkan $\mathrm{H}_{1}$ diterima, artinya ada pengaruh antara pengembangan karir, motivasi dan sikap secara simultan dan signifikan terhadap produktivitas kerja karyawan PT. BCA Multifinance Surakarta.

\section{Hasil uji t}

Perhitungan uji $t_{\text {hitung }}$ adalah:

Tabel 6. Hasil Uji t

\begin{tabular}{lcccl}
\hline \multicolumn{1}{c}{ Model } & $\mathrm{B}$ & $\mathrm{t}$ & Sig. & Keterangan \\
\hline Pengembangan Karir & 0,349 & 2,545 & 0,015 & $\mathrm{H}_{2}$ diterima \\
Motivasi & 0,393 & 2,396 & 0,021 & $\mathrm{H}_{3}$ diterima \\
Sikap & 0,274 & 2,144 & 0,038 & $\mathrm{H}_{4}$ diterima \\
\hline
\end{tabular}

Nilai $t_{\text {hitung }}>t_{\text {tabel }}(2,545>2,017)$ dan nilai signifikansi $0,015<0,05$ maka Ho ditolak dan $\mathrm{H}_{2}$ diterima. Dapat disimpulkan bahwa ada pengaruh positif dan signifikan pengembangan karir terhadap produktivitas kerja karyawan PT. BCA Multifinance Surakarta. 
Nilai $t_{\text {hitung }}>\mathrm{t}_{\text {tabel }}(2,396>2,017)$ dan nilai signifikansi $0,021<0,05$ maka Ho ditolak dan $\mathrm{H}_{3}$ diterima. Dapat disimpulkan bahwa ada pengaruh positif dan signifikan motivasi terhadap produktivitas kerja karyawan PT. BCA Multifinance Surakarta.

Nilai $t_{\text {titung }}>t_{\text {tabel }}(2,144>2,017)$ dan nilai signifikansi $0,038<0,05$ maka Ho ditolak dan $\mathrm{H}_{4}$ diterima. Dapat disimpulkan bahwa ada pengaruh positif dan signifikan sikap terhadap produktivitas kerja karyawan PT. BCA Multifinance Surakarta.

\section{Hasil uji koefisien determinasi}

Perhitungan nilai koefisien determinasi adalah:

Tabel 7. Hasil Koefisien Determinasi

\begin{tabular}{ccc}
\hline$R$ & $R$ Square & Adjusted $R$ Square \\
\hline 0,741 & 0,549 & 0,518 \\
\hline
\end{tabular}

Berdasarkan hasil analisis di atas maka diperoleh nilai Adjusted $R$ Square sebesar 0,518 atau $51,8 \%$. Determinasi atau sumbangan variabel pengembangan karir, motivasi dan sikap terhadap produktivitas kerja karyawan PT. BCA Multifinance Surakarta sebesar 51,8\%. Sisanya sumbangan variabel-variabel lain hanya sebesar $48,2 \%$ seperti pengetahuan, keterampilan, kebiasaan dan lain-lain.

\section{PEMBAHASAN}

Berdasarkan hasil uji $\mathrm{F}$ maka diketahui $\mathrm{F}_{\text {hitung }}>\mathrm{F}_{\text {tabel }}(17,459>2,82)$ dan signifikansi 0,000 $<0,05$, maka Ho ditolak $\mathrm{H}_{1}$ diterima. Artinya pengembangan karir, motivasi dan sikap secara simultan dan siginifikan berpengaruh terhadap produktivitas kerja. Hasil tersebut membuktikan semakin tinggi pengembangan karir, motivasi dan sikap maka pada produktivitas kerja akan mengalami peningkatan secara nyata.

Berdasarkan analisis uji $t$ diperoleh hasil nilai $t_{\text {hitung }}>t_{\text {tabel }}(2,545>2,017)$, nilai signifikansi $0,015<0,05$ dan koefisien regresi mempunyai nilai positif sebesar 0,349 , maka Ho ditolak $\mathrm{H}_{2}$ diterima. Artinya pengembangan karir berpengaruh positif dan signifikan terhadap produktivitas kerja. Apabila pengembangan karir yang ada semakin tinggi, maka produktivitas kerja akan meningkat. Penelitian ini sejalan dengan penelitian sebelumnya yang dilakukan oleh Ismail, Rahma dan Pratiwi (2015) pengembangan karir berpengaruh positif dan signifikan terhadap produktivitas kerja. Pengembangan karir berpengaruh terhadap produktivitas kerja karyawan PT. BCA Multifinance Surakarta karena latar belakang pendidikan yang dimiliki cukup untuk mengembangkan karir. Perusahaan selalu memberikan pelatihan rutin setiap satu bulan sekali. Adanya pelatihan yang diadakan perusahaan membuat karyawan mendapat keahlian tertentu dan dapat digunakan dalam menyelesaikan tugas dan tanggung jawab. Selain itu, karyawan juga memiliki cukup pengalaman yang dapat digunakan untuk mengembangkan karir. Adanya pengembangan karir dapat digunakan untuk memberikan kesempatan kepada karyawan untuk bekerja lebih baik sesuai dengan keterampilan dan keahlian. Sehingga produktivitas kerja meningkat, karyawan semakin semangat dalam bekerja dan loyal terhadap perusahaan.

Berdasarkan analisis uji $t$ diperoleh hasil nilai $t_{\text {hitung }}>t_{\text {tabel }}(2,396>2,017)$, nilai signifikansi $0,021<0,05$ dan koefisien regresi mempunyai nilai positif sebesar 0,393 , maka Ho ditolak $\mathrm{H}_{2}$ diterima. Artinya motivasi berpengaruh positif dan signifikan terhadap produktivitas kerja. Apabila motivasi yang ada semakin tinggi, maka akan meningkatkan produktivitas kerja. Penelitian ini sejalan dengan penelitian sebelumnya yang dilakukan oleh Febrianti dan Ani (2019) motivasi berpengaruh secara positif dan signifikan terhadap produktivitas kerja. Motivasi 
berpengaruh terhadap produktivitas kerja karyawan PT. BCA Multifinance Surakarta. Upaya yang dilakukan perusahaan dalam meningkatkan motivasi karyawan seperti menciptakan kondisi kerja yang menyenangkan, diwujudkan dengan memberikan lingkungan kerja nyaman, seperti ruangan kerja bersih dan fasilitas yang diberikan lengkap. Peningkatan motivasi dilakukan perusahaan dengan memberi penghargaan kepada karyawan yang berprestasi, penghargaan tersebut berupa promosi jabatan maupun kenaikann insentif. Selain itu, karyawan memiliki hubungan yang baik dengan rekan kerja maupun dengan atasan. Saat karyawan mengalami kesulitan dalam menyelesaikan tugas dan tanggung jawab, karyawan lain bersedia untuk membantu.

Berdasarkan analisis uji $t$ diperoleh hasil nilai $t_{\text {hitung }}>t_{\text {tabel }}(2,144>2,017)$, nilai signifikansi $0,038<0,05$ dan koefisien regresi mempunyai nilai positif sebesar 0,274 , maka Ho ditolak $\mathrm{H}_{4}$ diterima. Artinya sikap berpengaruh positif dan signifikan terhadap produktivitas kerja. Apabila sikap yang ada semakin tinggi, maka produktivitas kerja akan meningkat. Penelitian ini sejalan dengan penelitian sebelumnya yang dilakukan Asmuni dan Widiastuti (2015) sikap berpengaruh positif dan signifikan terhadap produktivitas kerja. Sikap berpengaruh terhadap produktivitas kerja karyawan PT. BCA Multifinance Surakarta. Adanya sikap yang positif seperti karyawan yang pandai menghargai waktu, disiplin tinggi, memiliki tanggung jawab tinggi terhadap pekerjaan. Adanya sikap positif dari karyawan membuat perusahaan memberikan kesempatan kepada karyawan untuk mendapatkan fasilitas maupun bonus. Selain itu sikap pimpinan yang memberikan bawahan untuk berkreativitas dalam mengembangkan kemampuan dan keahlian. Sikap positif yang dimiliki karyawan seperti menyenangi pekerjaan akan dapat meningkatkan produktivitas kerja. Karyawan yang bersikap baik, berupaya maksimal memberikan hasil kerja terbaik dengan cara mematuhi standar operasional prosedur yang diberlakukan dalam perusahaan.

\section{KESIMPULAN}

Ada pengaruh simultan dan signifikan pengembangan karir, motivasi dan sikap terhadap produktivitas kerja karyawan PT. BCA Multifinance Surakarta. Pengembangan karir berpengaruh positif dan signifikan terhadap produktivitas kerja karyawan PT. BCA Multifinance Surakarta. Motivasi berpengaruh positif dan signifikan terhadap produktivitas kerja karyawan PT. BCA Multifinance Surakarta. Sikap berpengaruh positif dan signifikan terhadap produktivitas kerja karyawan PT. BCA Multifinance Surakarta.

\section{DAFTAR PUSTAKA}

Arikunto, S. (2016). Prosedur Penelitian : Suatu Pendekatan Praktik. Jakarta: Rineka Cipta

Asmuni, \& Widiastuti, T. (2015). Pengaruh Pengetahuan, Keterampilan, Kemampuan, Sikap, Perilaku terhadap Produktivitas (Studi pada Karyawan PT Lukie Works Indonesia). Jurnal Aset 14(2), 95-108

Ghozali, I. (2015). Aplikasi Analisis Multivariate dengan Program SPSS. Edisi ketujuh. Semarang: Badan Penerbit Universitas Diponegoro

Handoko, T.H. (2016). Manajemen Personalia dan Sumber Daya Manusia. Yogyakarta: BPFE 
Hartanto, W., Febrianti, N.R., \& Ani, H.M. (2019). Pengaruh Motivasi Kerja dan Pengalaman Kerja Terhadap Produktivitas Tenaga Kerja Pengrajin Kuningan di Kecamatan Tapen Kabupaten Bondowoso. Jurnal Pendidikan Ekonomi 13(1), 42-49

Ismail, Z., Rahma, S., \& Pratiwi, D. (2015). Analisis Pengaruh Pelatihan dan Pengembangan Karir Terhadap Produktivitas Kerja Pegawai (Studi Kasus Pada PT Bank Sumsel Babel Cabang Pangkalpinang). Jurnal Ilmiah Progresif Manajemen Bisnis 4(2), 16-26

Kustiyah, E., Pawastri, N., \& Istiatin. (2018). Pengaruh Pelatihan, Reward dan Kepuasan Kerja terhadap Produktivitas Kerja Karyawan pada PT Kusumahadi Santosa Karanganyar. Jurnal Manajemen dan Keuangan 7(1), 73-81

Mangkunegara, A.P. (2016). Manajemen Sumber Daya Manusia Perusahaan. Bandung:

PT Remaja Rosdakarya

Moenir. (2014). Manajemen Pelayanan Umum Indonesia. Jakarta: Bumi Aksara

Sugiyono. (2016). Metode Penelitian Bisnis. Bandung: Alfabeta

Susanty, A., \& Miradipta, R. (2015). Employee's Job Performance: The Effect of Attitude toward Works, Organizational Commitment, and Job Satisfaction. Jurnal Teknik Industri $15(1), 15-24$

Swastha, B., \& Ibnu, S.W. (2015). Pengantar Bisnis Modern. Yogyakarta: Liberty

Syarif, R. (2015). Produktivitas. Jakarta: Depdikbud 